\title{
Clouds, airplanes, trucks and people: carrying radioisotopes to and across Mexico
}

\author{
Gisela Mateos (*) and Edna Suárez-Díaz (**) \\ (*) orcid.org/0000-0003-4288-4775. Centro de Investigaciones Interdisciplinarias en Ciencias y \\ Humanidades, UNAM. gisela.mateos@unam.mx \\ ${ }^{* *}$ ) orcid.org/0000-0003-2259-3110. Facultad de Ciencias, UNAM. ednasuarez@ciencias.unam.mx
}

Dynamis

[0211-9536] 2015; 35 (2): 279-305

http://dx.doi.org/10.4321/S0211-95362015000200002
Fecha de recepción: 28 de junio de 2014

Fecha de aceptación: 26 de marzo de 2015

SUMMARY: 1.-Introduction. 2.-Radioisotopes in boxes, the Atoms for Peace initiative, and the Mexican connection(s). 3.-The atomic fallout network: radioisotopes in clouds. 4.-Producing, preparing and packing radioisotopes in Mexico. 5.-Concluding remarks.

ABSTRACT: The aim of this paper is to describe the early stages of Mexican nuclearization that took place in contact with radioisotopes. This history requires a multilayered narrative with an emphasis in North-South asymmetric relations, and in the value of education and training in the creation of international asymmetrical networks. Radioisotopes were involved in exchanges with the United States since the late 1940s, but also with Canada. We also describe the context of implementation of Eisenhower's Atoms for Peace initiative in Mexico that opened the door to training programs at both the Comisión Nacional de Energía Nuclear and the Universidad Nacional Autónoma de México. Radioisotopes became the best example of the peaceful applications of atomic energy, and as such they fitted the Mexican nuclearization process that was and still is defined by its commitment to pacifism. In 1955 Mexico became one of the 16 members of the atomic fallout network established by the United Nations. As part of this network, the first generation of Mexican (women) radio-chemists was trained. By the end of the 1960s, radioisotopes and biological markers were being produced in a research reactor, prepared and distributed by the CNEN within Mexico. We end up this paper with a brief reflection on North-South nuclear exchanges and the particularities of the Mexican case.

KEY WORDS: Radioisotopes, nuclearization, Atoms for Peace, fallout, radiochemistry. 


\section{Introduction (*)}

Between the late 1940s and the 1960s, radioisotopes and radioactive materials travelled around the world in a myriad of media: boxes, airplanes, trucks, containers, and clouds. They also travelled in all directions: EastWest, West-East, South-North and North-South. Some of them travelled as commodities, some as raw materials, and some as atmospheric trash. In all cases radioisotopes were instrumental in the construction of local nuclear projects and the production of standardized nuclear practices through the establishment of international networks. Around radioisotopes new scientific communities were formed and trained in some of the fields of the atomic era: in the Mexican case, cloud radioisotopes played a crucial role in the training of radio-chemists, while radioisotopes as commodities were used in medicine, agriculture, biology, geology, archaeology, and industry. In the mid-1960s both kinds of practices were reunited at the Mexican Nuclear Center of the National Nuclear Energy Commission (Comision Nacional de Energía Nuclear, CNEN), built at the village of Salazar, a few miles northwest from Mexico City.

The aim of this paper is to describe the early stages of Mexican nuclearization that took place in contact with radioisotopes. But a word of warning deserves to be said on definitions of nuclearization, and how these reflect assumed points of departure in the writing of history. Although not defined in major dictionaries (like Oxford or Webster), nuclearization is defined in English as «deployment of atomic weapons by a nation» or «the acquisition by a nation, or supplying to a nation, of nuclear weapons» ${ }^{1}$; while the same term is used in Spanish to make reference to «the substitution of traditional energy sources for nuclear sources, and the deployment of atomic weapons» ${ }^{2}$. We will use nuclearization in its broad accepted Spanish meaning, including a broad range of materials (particularly, radioisotopes), activities and degrees to which Mexico was involved in nuclear matters.

$\left(^{*}\right)$ Our research has been possible thanks to a research grant from CONACyT (152879), as well as a PAPIIT-UNAM research-grant (IN4003143).

1. Available at: http://www.thefreedictionary.com/nuclearization; http://www.collinsdictionary. com/dictionary/nuclearization.

2. Available at: http://es/thefreedictionary.com. 
In doing so, we follow the idea of Herran and Roqué, that «isotopes work as tracers of modern technoscience that invite historical research» ${ }^{3}$. This idea has been advanced by Angela Creager, who has traced the ways in which radioisotopes were introduced into experimental systems, circulated and enabled new developments ${ }^{4}$. We wish to extend the idea in a slightly different direction, namely, understanding radioisotopes as tracers of geopolitical relations. Thus, in contrast to earlier accounts of the exchanges of radioisotopes between the United States and Europe ${ }^{5}$, our history requires a multilayered narrative with an emphasis in NorthSouth asymmetric relations, and in the value of education and training in the creation of international asymmetrical networks.

Mexico's relation to nuclear things started soon after the bombings of Hiroshima and Nagasaki, and took place along different and simultaneous paths $^{6}$. On August 22nd 1945, president Miguel Alemán (1944-1950)

3. Herran, Néstor; Roqué, Xavier. Tracers of modern technoscience. Dynamis. 2009; 29: 123-130 (123).

4. Creager, Angela. Life Atomic. A History of Radioisotopes in Science and Medicine. Chicago: The University of Chicago Press; 2013. See also n. 5.

5. Creager, Angela. Tracing the politics of changing postwar research practices: the export of «American» radioisotopes to European biologists. Studies in the History and Philosophy of Biology and Biomedical Sciences. 2002; 33: 367-388; Krige, John. The Politics of Phosphorus-32. A Cold War fable based on fact. Historical Studies in the Physical and Biological Sciences. 2005; 36 (1): 71-91; Creager, Angela. Radioisotopes as political instruments; 1946-1953. Dynamis. 2009; 29: 219-240; Creager, Angela; Santesmases, María Jesús. Radiobiology in the atomic age. Changing research practices and policies in comparative perspective. Journal for the History of Biology. 2006; 39: 637-647; Santesmases, María Jesús. Peace propaganda and biomedical experimentation: Influential uses of radioisotopes in endocrinology and molecular genetics in Spain (1947-1971). Journal of the History of Biology. 2006; 39: 765-794; Turchetti, Simone. A contentious business: Industrial patents and the production of isotopes, 1930-1960. Dynamis. 2009; 29: 191-217.

6. Mateos, Gisela; Suárez-Díaz, Edna. Peaceful atoms in Mexico. In: Medina, Eden; Holmes, Christina; Da Costa, Ivan. STS in Latin America: Beyond imported magic. Cambridge: MIT Press; 2014, p. 287-303. Mateos, Gisela; Suárez-Díaz, Edna. Tensions between becoming nuclear and promoting denuclearization: Mexican nuclear politics, 1950-1970. Conference Dark Matters: Contents and Discontents of Cold War Science, Barcelona, May 2013. For other aspects of Mexican's uses of nuclear energy see Azuela, Luz Fernanda; Talancón, José Luis. La historia de la energía nuclear en México, 1945-1995. México: CEPE, IIS, IG y Plaza y Valdés; 1999; Domínguez, Raúl. Historia de la Física Nuclear en México, 1933-1963. México: CESU-UNAM/ Plaza y Valdés; 2000; Vélez Ocón, Carlos. Cincuenta años de energía nuclear en México 19451995, México: Universidad Nacional Autónoma de México; 1997. On Mexican reactions to the atomic bomb, Cabral, Regis. The Mexican reactions to the Hiroshima and Nagasaki tragedies of 1945. Quipu. 1987; 4 (1): 81-118. 
declared the national oversight and control of all uranium, thorium and other fissionable reserves in national soil; in 1950 the so-called Alemán Law asserting national ownership over fissionable materials was passed by the Mexican Congress ${ }^{7}$. In the few weeks after the bombings, national newspapers publicized the presence of uranium reserves in the Northern state of Chihuahua, and emphasized the importance of scientific development for countries like Mexico. Scientists, such as MIT-educated physicist Manuel Sandoval Vallarta (see below), and media, joined efforts to ask for stronger support of education, universities, and research ${ }^{8}$. The outcry complemented Alemán's presidency, which was characterized by a state narrative focused on modernization, understood as the need for a rapid industrialization, growth of internal markets, as well as promotion of science and higher education ${ }^{9}$. Indeed, one of the best examples of Alemán's policies was the construction of the new campus of the National University of Mexico (UNAM) in Southern Mexico City, where new buildings for the Physics Institute and the School of Sciences were located. A Van de Graaff accelerator from the High Voltage Energy Corporation at Boston, Massachusetts was also acquired as a symbol of modernization ${ }^{10}$. Mural paintings by the

7. Diario Oficial de la Federación, 26 Ene 1950. Starting in 1946, the United States Atomic Energy Commission (AEC) would analyze Mexican uranium ore «transmitted samples» (or «dispatches») sent by the US Embassy in Mexico and from individual agents. In general, results were negative or, as in the case of dispatch 4821 (October 7, 1947) from the state of Chihuahua, «not considered of any significant potential importance». National Archives and Record Administration (hereafter NARA), Washington D. C. Record Group 59. General Records of the Department of State, General Records Relating to Atomic Matters, 1948-1962, Box 51.

8. Cabral, n. 6 .

9. After the mid-1950s the discourse of modernity overlapped with that of development, and during the 1960s development dominated international relations. For «less developed countries» development programs included the peaceful uses of atomic energy (see below). As Sujit Sivasundaram has suggested «Indeed, the question of modernity is one that needs to be addressed squarely by global historians science. To be modern in a global age of knowledge, by the twentieth century, meant using science and technology to intervene in problems of hunger, disease and development. Such modernity meant the tying of knowledge into the national economy... what is interesting is that modernity did not lead to the flattening out of various traditions of expertise across the world. Instead, the modern and the traditional coexisted, entangled to the extent that being modern was sometimes proved by recourse to rejecting traditions while at other times it was about updating traditions or recovering lost ones». Sivasundaram, Sujit. Sciences and the global: on methods, questions and theory. Isis. 2010; 101: 146-158 (156).

10. Though the initial contact to buy the accelerator (at a selling price of $\$ 113,000.00$ USD) occurred in 1950, the instrument was not in place until 1953, installed at the new campus of the UNAM, as part of the Physics Institute. The history of the charged ideological and 
most prestigious Mexican muralists decorated the walls of the campus and displayed a visual discourse connecting progress, modernity with science, and in particular atomic energy.

Though Mexico did not have a tradition in nuclear physics at the time, a few physicists and engineers, who were well connected with academic institutions in the United States, acted as expertise agents for the Mexican government in the first years of the United Nations and the nuclear age ${ }^{11}$. By the time of Eisenhower's Atoms for Peace speech at the United Nations General Assembly (December 8th 1953), a small group of Mexican scientists and engineers was becoming already acquainted both with nuclear practices and, equally important, with the diplomatic skills required for the new world order. This group included the rector of UNAM and Harvard educated soil mechanics engineer Nabor Carrillo (the most enthusiastic Mexican promoter of nuclear technologies); MIT former professor and Vannevar Bush collaborator, physicist Manuel Sandoval Vallarta; UNAM's Physics Institute director Carlos Graef; the first Mexican graduated physicist and future director of the Physics Institute, Fernando Alba Andrade; as well as former Supreme Court president José María Ortíz Tirado, who would become the first director of the Mexican atomic agency (CNEN) in December 1956, a few months before the formal constitution of the International Atomic Energy Agency (IAEA). Though the Atoms for Peace initiative has been

technical decisions operating in the purchase of the Mexican Van de Graaff accelerator has been carefully narrated on the Mexican side by Mateos, Gisela; Minor, Adriana; Sánchez, Valeria. Una modernidad anunciada: Historia del Van de Graaff de la ciudad universitaria. Historia Mexicana. 2012; 61 (1): 415-442; Minor, Adriana. Instrumentos científicos en movimiento. Historia del acelerador Van de Graaff del Instituto de Física de la UNAM (1950-1983). Tesis de Maestría; Universidad Nacional Autónoma de México; 2011. The files concerning the US Department of State «export license application» for the 2 MeV Van de Graaff point to Nabor Carrillo, Manuel Sandoval Vallarta, Alberto Barajas (Director of the School of Sciences) and Carlos Graef Fernández as the scientists supervising the acquisition «for fundamental physics research». NARA, Record Group 59. General Records of the Department of State, General Records relating to Atomic Matters, 1948-1962, Box 51.

11. This was in contrast to Argentina and Brazil. Hurtado de Mendoza, Diego. Autonomy, even regional hegemony: Argentina and the «Hard Way» toward its first research reactor (19451958). Science in Context. 2005; 18 (2): 285-308; Ribeiro de Andrade, Ana M.; Muniz, R. P. A. The quest for the Brazilian synchrocyclotron. Historical Studies in the Physical and Biological Sciences. 2006; 36 (2): 311-327; Hurtado de Mendoza, Diego; Vara, Ana María. Winding roads to Big Science: Experimental physics in Argentina and Brazil. Science, Technology \& Society. 2007; 12: 27-48; Patti, Carlo. The origins of the Brazilian Nuclear Programme, 1951-1955. Cold War History (article in the Internet). 2014. (quoted on 17 Dec 2014). Available at: http://www. tandfonline.com/doi/abs/10.1080/14682745.2014.968557\#.VJHWg4dRZOs. 
credited with being responsible for the promotion of nuclear technologies in the world, the Eisenhower initiative did not produce an unidirectional US-government program ${ }^{12}$. It was, first, a concerted co-production that included federal agencies, industrial funds and universities within the United States. In most cases, and in particular abroad, US government agencies (the Department of State through the Foreign Operations Agency, FOA) acted as branches of universities and industrial funds, while simultaneously dictating the US national policy directions. Second, the Atoms for Peace initiative soon incorporated and created international agencies (the IAEA in 1957 being the most obvious). But third and equally important, the Atoms for Peace initiative required the involvement (or recruit) of local actors, natural resources and infrastructures, governmental funding and standardized - but localized-techno-scientific practices in countries around the world. All of these elements contributed to shape the Eisenhower campaign in localized ways, as we will see in the case of Mexico.

In what follows, we will describe the context of implementation of the Atoms for Peace program in Mexico (section 2), which happened in consonance with the creation of the CNEN and the IAEA. Radioisotopes had been involved as commodities in exchanges starting a few years before, mainly with the United States, but also with Canada. The Eisenhower initiative, however, opened the door to participate in new training programs, which set the context for a broader radioisotope program at both CNEN and UNAM. Moreover, in 1955 Mexico became one of the 16 members of the atomic fallout network established by the United Nations, with US AEC promotion and backing. As part of this network, the first generation of Mexican (women) radio-chemists was trained, in contact with radioisotopes travelling in clouds (section 3). By the end of the 1960s, radioisotopes and biological markers were being produced, prepared and distributed within Mexico by the CNEN (section 4). We end up this paper with a brief reflection on North-South nuclear exchanges and the particularities of the Mexican case.

12. Recent interpretations of the Atoms for Peace initiative emphasize its central role in the global national security strategy and propaganda of the Eisenhower administration. See Medhurst, Martin, J. Atoms for Peace and nuclear hegemony: The rhetorical structure of a Cold War Campaign. Armed Forces \& Society. 1997; 23(4): 571-593; Osgood, Keneth. Total Cold War. Eisenhower's secret propaganda battle at home and abroad. Lawrence: University Press of Kansas; 2006, p. 153-180. 


\section{Radioisotopes in boxes, the Atoms for Peace initiative, and the Mexican connection(s)}

The General Hospital of the Mexican Health and Assistance Ministry (Hospital General de la Secretaria de Salud y Asistencia), and the private Laboratorios Clínicos de México S. A., received the first US radioisotope shipment in 1949. The Iodine-131 cargo had been shipped on August 23th from Oak Ridge National Laboratory (ORNL, which had changed its name from the Clinton Laboratories in 1948) for the treatment of thyroid cancer and related thyroid diseases. Almost one year later, on July 25th 1950, a Cobalt-60 shipment arrived to substitute the radio source at the Hospital Civil de Guadalajara (in western Mexico) for cancer treatment. In the fall of 1947 the US AEC had lifted the radioisotope embargo to foreign distribution that had been in place for one year ${ }^{13}$, and though the first shipment was sent to Australia, the main early recipients were European countries ${ }^{14}$. Latin American countries, however, also benefitted from the recently established international shipment program: in 1947 recipients included the atomic regional powers of Argentina and Brazil, as well as Colombia and Chile ${ }^{15}$. According to the US Atomic Energy Act, exported radioisotopes should be used for therapeutic applications and biomedical research in their final destinations; industrial uses were forbidden during the first years. Moreover, upon reception of the radioisotopes, countries accepted that US inspectors could visit their research facilities at any moment in order to check how the materials were being used. Given the above constraints, it was not until 1954 that the Mexican Light and Power Company Ltd. (then, a Canadian owned company) bought a shipment of Iridium-91 and Cobalt-60 to Canada for industrial uses ${ }^{16}$.

Economic, political and scientific asymmetries underlie the exchange between these «distant neighbors» ${ }^{17}$. The radioisotope journeys between

\footnotetext{
13. The Atomic Energy Act had been passed on August $1^{\text {st }}$ of 1946 by the US Congress.

14. Creager 2002 and 2009, n. 5.

15. Creager 2002, n. 5. We thank Angela Creager for her generous sharing of information concerning international radioisotope shippings in those early years.

16. Nationalization of natural resources and energy production had reached its climax during Lázaro Cardenas' presidency (1934-1949), when oil companies were expropriated. The process had come to a halt in the following decades, but the Mexican Light and Power Company Ltd. was nationalized in 1960 by president Adolfo López Mateos.

17. Riding, Alan. Distant neighbors. A portrait of the Mexicans. New York: Alfred Knopf; 1985.
} 
the United States and Mexico played out in the different kinds of materials and people who travelled across the «Rio Grande» (from the US side) or the «Río Bravo» (from the Mexican side). This point is made more obvious when we pay attention to the ways in which US officials characterized the nuclear path that Mexico was supposed to follow, via technical assistance, as a member of what they classified as the «less developed» countries ${ }^{18}$. According to a memo of October 20th, 1955, American technical assistance was unnecessary for «advanced» countries like the United Kingdom, Belgium, France, Norway, and Holland. Then, there was a second group of countries where assistance could arrive immediately, including Denmark, Japan, Spain, and Italy. And,

«[...] following these, would come a group of about eight countries worthy of attention for immediate development of a longer term program including, as the first phase, research reactors and isotope centers. These would include Turkey, Mexico, Argentina, Philippines, Pakistan, Israel, Yugoslavia and Thailand. Argentina has been listed in this latter group, but might very well be included with India and Brazil upon further study» ${ }^{19}$.

Though for some time the US and the Mexican interests coincided, the Mexican scientists and government had their own perspective, and in the following years they reacted to preserve «national sovereignty», using a combination of reliance on international agencies and scientific diplomacy. As Krige has pointed out, radioisotopes acted as diplomatic tools in the relation of the USA and the rest of the world ${ }^{20}$, and during the early years of the Cold War Mexicans used them as prime symbols of their peaceful (and highly diplomatic) relation to atomic energy, and their differentiation

18. As mentioned above the discourse of development took over transactions between the US and Mexico (and Latin America) by the mid-1950s. Sivasundaram, n. 9. The inclusión of peaceful applications of atomic energy in education exchange programs and other development programs is most evident in the creation of the Inter-American Nuclear Energy Commision (IANEC) in 1957. The IANEC was part of the Organization of American States in 1957 (and it is the subject of a forthcoming paper).

19. Memorandum from Blythe Stason (Director of Fund for Peaceful Atomic Development, Inc., FPAD, and Dean of Michigan University Law School) to W. Keneth Davis, Director of US AEC Reactor Development Division. NARA Record Group 59 General Records of the Department of State. Office of the Secretary Special Asst. to Sec. of State for Atomic Energy and Outer Space. General Records relating to Atomic Energy Matters, 1948-1962. Box 297 (old box 214).

20. Krige, John. Atoms for Peace; scientific internationalism and scientific intelligence. Osiris. 2006; 21: 161-181. 
from the military purposes of atomic energy in the USA and other Latin American countries (namely, Brazil and Argentina) ${ }^{21}$. The shipment and applications of radioisotopes thus implied more than their material journey across the border. Radioisotopes symbolized the civil uses of nuclear energy, despite the fact that (at least for those materials coming from the USA) they were produced by the same instruments used to produce materials for atomic bombs 22 .

In the case of Mexico the radioisotope trips required that students and researchers traveled to the United States to learn radiochemistry, nuclear engineering, and radiological methods and applications. In the opposite direction, researchers, functionaries, and nuclear advisors travelled to Mexico (specifically, to Mexico City), in order to explore, supervise and collaborate with the nascent nuclear community. Clearly, radioisotopes were not the only ones crossing frontiers. Practices, knowledge, people, as well as symbols and meanings, travelled with them.

The year 1955 was a busy time for the Mexican group, with nuclear issues moving fast. Before the International Conference on the Peaceful Uses of Atomic Energy took place in Geneva from August 8th to 20th ${ }^{23}$, the Mexican enthusiasts leaded by Carrillo had already approached a couple of US universities to engage in nuclear technical assistance and education programs. Gustave Maryssael, President of the Canadian Electric Force and Power Co. operating in Mexico, had also joined the group, in search of opportunities for nuclear produced electricity. The most important contact took place in April 1955, when the Mexicans approached the recently created Fund for Peaceful Atomic Development (FPAD), with headquarters in the Edison Corporation of Detroit, but operating at the University of Michigan in Ann Arbor. The FPAD had been created in 1954 in the aftermath of Eisenhower's speech; it was a conglomerate of industries with transnational

21. Mexico did not formally belong to the non-aligned movement (for reasons that are beyond this paper); nevertheless, the Mexican government was a close observer of the movement. In October 1962 President Adolfo López Mateos («the great denuclearizator of Latin America», as some official documents call him), travelled to India, Japan, the Philippines, and Indonesia. In India, together with Prime Minister Nehru they signed a joint declaration on behalf of the preservation of peace. Vázquez, Josefina Zoraida; Meyer, Lorenzo. México frente a Estados Unidos. Un ensayo histórico, 1776-2000. México: Fondo de Cultura Económica; 2001. On Argentina and Brasil see n. 11.

22. Creager, 2013, n. 5 .

23. The Mexican delegation to the first Geneva meeting included Alba Andrade and Carlos Graef. 
presence (including, among others, the Ford Fund, General Motors and United Fruit Co.) and universities (Michigan, California), which acted in concert with the US State Department, and whose public face was a large endowment called the Michigan Memorial-Phoenix Project (created in 1948). The purposes of the fund were described as follows:

«[...] to provide an international clearinghouse for the exchange of unclassified information with respect to private uses of nuclear forces; to provide scholarships, fellowships, and training facilities to permit persons in foreign countries to engage in educational programs in the United States relative to nuclear enterprise; and to conduct meetings and conferences, both in the United States and abroad, for the purposes of promoting knowledge and understanding of peaceful uses of atomic energy and for the drafting of model regulations and legislation» 24 .

E. Blythe Stason, Dean of the Law School at the University of Michigan, was designated Managing Director of the FPAD Board, «because of his contributions to the new field of the law of atomic energy». Indeed, Stason had studied mechanical engineering in the MIT, before graduating in law in 1922 from Michigan; then, in 1954 he «had been appointed as Chairman of the Special Committee of the American Bar Association on Atomic Energy Law». The committee had been involved in the adoption and drafting of most of the law of the Atomic Energy Act in 1954 ${ }^{25}$. Moreover, from 1951 to 1959 Stason was involved in research on atomic matters and law, becoming a leading world expert on legal issues of atomic energy ${ }^{26}$. As managing director of the FPAD, Stason also acted as the connection between the fund and the US Department of State, besides being a member of the Inter-American Bar Association.

Stason was helped, among others, by Assistant Director Henry J. Gomberg, an expert on nuclear engineering. Between May 31st and June 5th 1955, both Stason and Gomberg and a small committee, arrived in Mexico City to meet Nabor Carrillo, at the moment UNAM's rector. Other scientists and functionaries, including Maryssael and Rodolfo Hernández

24. The President's report of regents for the academic year 1953-1954. 57 (17), 8 Aug 1955. Ann Arbor: University of Michigan Official Publication; 1955, p. 7.

25. Dethmers, J.R. E. Blythe Stason. Michigan Law Review. 1961; 59: 159-190 (181-182).

26. In 1959 together with Samuel D. Estep and William J. Pierce, he had published a huge volume entitled Atoms and the Law (Ann Arbor: Michigan Legal Publications; 1959). 
Corzo (Director of the Mexican National Polytechnic Institute, IPN) participated in the meeting. As part of the US committee also assisted Ross Moore, Director of Technical Cooperation of the International Cooperation Administration at the American Embassy in Mexico ${ }^{27}$. Among the goals of the small committee was:

«[...] to make available to students from Mexico, principally the University of Mexico, and the Monterrey Institute of Technology, the facilities and experiences of the University of Michigan in the work done under the auspices of the Phoenix Project in the field of Atomic Energy [...] for the purpose of working in laboratories in various aspects of the subject-food processing, medical diagnosis and therapy, chemical processing, the handling of isotopes, tracing, carbon-14 dating, etc. At the same time specialists from the University of Michigan will, on selected occasions go to Mexico City for the purpose of cooperating with nuclear physicists in Mexico, in seminars, lecture programs and consultations. As soon as a corps of trained Mexicans becomes available to serve as technicians and instructors in their own country, steps will probably be taken to assist Mexico in establishing suitable radiation laboratories and other isotope facilities. [...] Eventually this should lead Mexico to the experimental reactor stage ${ }^{28}$.

Indeed, the FPAD was instrumental in the education of the first generation of Mexican nuclear physicists and engineers, whose influence would be felt in the next two decades.

Moreover, the Mexicans were very enthusiastic of the possibilities opened up by the Michigan connection. In the trip report of the FDAP commission sent by Stason to the US State Department, he recounted that after a meeting on June 1st at the UNAM's rectory,

27. According to documents of the Department of State, the US Foreign Operations Agency (FOA) changed its name in Mexico, to Technical Cooperation Agency of the ICA, because of Mexican «nationalistic sensibilities», who did not like the implications of «foreign operations». Nevertheless, in internal documents of the ICA and FOA, the Mexican office used the more common FOA nomenclature. Stason, E. Blythe. Report of Activities. Fund for Peaceful Atomic Development Inc., January 1 to May 1, 1955, Ann Arbor, 10 May 1955, p. 5. NARA, Record Group 59. General Records of the Department of State. Office of the Secretary Special Asst. To Secretary of State for Atomic Energy and Outer Space. General Records relating to Atomic Energy Matters, 1948-1962. Box 297 (old box 214), 1 entry 3008-A.

28. Stason, p. 5-6,n. 27. The Instituto Tecnológico de Monterey was funded by the Mexican industrialist Eugenio Garza Sada in 1943 
«Dr. Carrillo closed the meeting with an unusually fervent and positive statement of the desire of the people of the university to participate in the development of peaceful uses of atomic energy. His statement was most eloquent and effective» ${ }^{29}$.

From the interaction between the FDAP and the Mexican group both parts benefited, but not in the same way. One of the first outcomes of the visit was that in the summer of 1955 eight Mexican students were sent to the University of Michigan to study nuclear engineering, seven of them with Mexican funding: Bruno de Vecchi Appendini and Carlos Vélez Ocón (from the Light and Power Co.), Arnulfo Morales Amado, and Vinicio Serment Cabrero (from UNAM), Antonio Magaña Plaza (IPN), Miguel Angel Barberena Vega, and Luis Gálvez Cruz (from the Veracruz University); and one receiving a fellowship from the US, Roberto Treviño Arizpe $^{30}$. From the US side, one of the priorities was the distribution of technology and the opening of nuclear reactors markets (for research and the production of electricity) to countries with incipient nuclear projects and geopolitical interest or significance. Mexico was an ideal target. When the first generation of nuclear scientists came back to Mexico, they became involved in the creation of research projects, laboratories, and groups in several fields at the Physics Institute at UNAM and the CNEN.

The 1955 and 1957 Geneva Meetings on the Peaceful Applications of Atomic Energy acted as catalysts of diplomatic, scientific, industrial and commercial agreements, mainly between the USA and countries willing to buy nuclear reactors ${ }^{31}$. Soon, the USSR jumped in to the international nuclear arena, and also offered training programs to other countries, including Mexico. Through its Embassy in Mexico City in July 1956 they offered studentships «for cadre training (formación de cuadros) [...] in the uses of atomic energy for pacific ends $[. .$.$] and receive students in the$ Physics Faculty of the USSR». The memorandum also specified:

«The students teaching expenses would be covered by the USSR. Students would receive studentships, a grant for acquiring textbooks and school materials, a grant for medical treatments in hospitals and for spending their

\footnotetext{
29. Stason, n. 27, p. 2.

30. Vélez Ocón, n. 6.

31. Krige, n. 20.
} 
vacations in the USSR; if necessary a grant will be given to acquire clothes; the free medical service and lodging in the students residence is guaranteed $»^{32}$.

Despite the Soviet offer, most of the Mexican physicists and engineers traveled to the US in order to get graduate studies, though later on (in the mid-1960s) radiochemists preferred to travel to the UK and France. The Mexicans had visible ties with their neighbors, but not always the relations between the two countries were easy, even after their WWII alliance. In 1952, for instance, a US commission had stayed in Mexico City for a twoweeks long stay, to try to convince the Mexican government and Army to sign a bilateral defense agreement, of the type most Latin American countries signed in the period. The Mexicans refused, arguing that the US military bases to be located in Mexican territory should be run by Mexicans ${ }^{33}$. Thus, at a time of increasing chilly relations between the US and the USSR, Mexico somehow managed to preserve an official neutral position, declaring its friendship to its powerful neighbor and at the same time keeping a very cordial relation with the USSR. Maneuver space was tight, but the Mexicans used it ${ }^{34}$. In the middle of this convoluted relation there were many areas of «cooperation» and «collaboration».

\section{The atomic fallout network: radioisotopes in clouds}

On December 3rd 1955, the United Nations adopted a resolution that established the Committee for the Studies of the Atomic Radiation Effects. The committee was a response to growing international concerns on the effects of atomic radiation, the increase of atmospheric atomic bomb detonations, and the armament race, and it had the explicit purpose to

32. Becas para hacer estudios en la Unión de Repúblicas Socialistas Soviéticas para Estudiantes. Archivo Genaro Estrada de la Secretaría de Relaciones Exteriores, México. Folder I11/811(47:72)/26370.

33. Vázquez; Meyer, n. 21.

34. Thanks to the recent opening of archives concerning Mexican security agencies (the Dirección General de Seguridad at the Archivo General de la Nación in Mexico City, in 2002) new historical interpretations have been published on the complex position of the Mexican government in relation to the US during the Cold War period. For an excellent study see Keller, Renata. A foreign policy for domestic consumption: Mexico's lukewarm defense of Castro, 1959-1969. Latin American Research Review. 2012; 47(2): 100-119. 
take fallout measures around the world ${ }^{35}$. Mexico, along with other 15 countries and territories became part of the committee, with the explicit commitment to take measures of atomic fallout in different locations, and study patterns of propagation. The preparatory meeting took place in 1956, and the Mexican representation was integrated by Manuel Martínez Báez (a physician that took part of the committee of experts for the creation of the World Health Organization), Horacio Zalce Torres (an oncologist and founder of the Mexican Society on Oncological Studies) and Alba.

A word is deserved to the atomic fallout network's composition, however. Of 37 chosen locations, 13 were US territories, or British and French colonies; six of the 37 were recently decolonized nations, and the rest were European and Latin American countries. In many of these places colonial-era meteorological and astronomical stations already existed, and in countries like Mexico a nascent infrastructure was in place ${ }^{36}$. The measurements taken in these countries were to be collected in a US data bank under the supervision of Merrill Eisenbud's group at the AEC. Eisenbud, who was in charge of the AEC Health and Safety Laboratory, had taken similar measures throughout the US since 1952. He and his group also developed simple standard sampling methods, which were highly mobile around the US territory. As a result of this experience, Eisenbud wrote the technical report that worked as the manual imposed as the standard protocol by the UN committee to carry out the fallout measures ${ }^{37}$. The preferred Eisenbud's methods included the use of «mundane technologies», such as gummed paper and water, whose surface was supposed to catch the airborne dust that was passed through filter paper and later dry-ashed, so the beta activity could be measured by counter instruments (Geiger

35. In 1952 the United States had 841 nuclear weapons, while by 1960 this number had increased to 18,683 . Krige, n. 20, p. 162.

36. The countries and territories belonging to the network were: Canada, Iceland, Bermuda, Mexico, Costa Rica, Panama Canal Zone, Colombia, Ecuador, Peru, Bolivia, Brazil, Argentina, Scotland, Norway, Germany, Morocco, Libya, French West Africa (now Senegal), Nigeria, Belgian Congo, Ethiopia, Union of South Africa, Ceylon, Malaya, Japan, Taiwan, Philippine Islands, Caroline Islands, Wake Island, New Caledonia, Australia, New Zealand, Johnston Island, Canton Island, Saudi Arabia, Lebanon, Puerto Rico. Eisenbud, Merril. Monitoring network for measuring radioactive fallout. Journal of the American Water Works Association. 1956; 48: 659-664.

37. Eisenbud, Merrill; Harley, John, Proposed uniform procedures for collection of fallout samples. Submitted to the UN Scientific Committee on the Effects of Atomic Radiation. New York: United Nations; 1956. 
counters were readily available) ${ }^{38}$. The gummed paper method was even easier to perform than the water method, and so it became the preferred procedure of the international network. Although the manual tried to standardize the measurement methods, every national team had to adapt them and re-create them to the local environment. Clearly, these were cheap technologies, requiring low investment from the US and international agencies to carry research in remote locations. However, these technologies provided valuable data, eagerly incorporated in the centers of calculation situated in the US ${ }^{39}$. The committee, thus, illustrates the fact that networks are not symmetrical structures: in this case the asymmetry is shown by the different roles played by the US and the rest of the countries participating.

In Mexico City, the new buildings of the recently inaugurated UNAM campus (Ciudad Universitaria) provided the landscape in which the first radioisotopes clouds were detected and measured. First, the building of the Van de Graaff Laboratory (figure 1), then the Sciences Tower (the 10th floor was occupied by the Physics Institute) hosted the first fallout instruments.

Measurements were also taken at the Astronomical Observatory at Tonanzintla, Puebla, and incorporated them in the first report ${ }^{40}$. Following the UN-Eisenbud's manual, the Mexican team applied the gummed paper and the water surface method. The accessibility of these technologies and practices is reflected in the description of measurements taken between May and August 1956: «Minnesota Manufacturera» brand gummed paper was glued to a tin-plate frame over a supporting structure (figure 2). This was left at the flat roofs of the buildings between 24 to 48 hours; the papers were dry-ashed and passed through different chemical processes, and finally beta activity was measured with a «Nuclear Chicago» brand Geiger-Muller counter and two ones from the «Anton» brand.

38. Eisenbud, M.; Harley, John H. Radioactive dust from nuclear detonations. Science, New Series. 1953; 117: 141-147.

39. Standardization, understood as the result of the action of «centres of calculation», is crucial to understand how countries like Mexico became part of the nuclear era. On the idea of centres of calculation Latour, Bruno. Science in Action. Cambridge: Harvard University Press; 1987. The geopolitical implications of the idea need to be explored for the Mexican-UN (AEC) case.

40. Alba Andrade, Fernando; Beltrán, Virgilio; Brody, Tomás A. et al. Primer informe sobre los estudios de lluvia radioactiva. Revista Mexicana de Física. 1956; 5 (4): 153-166. 


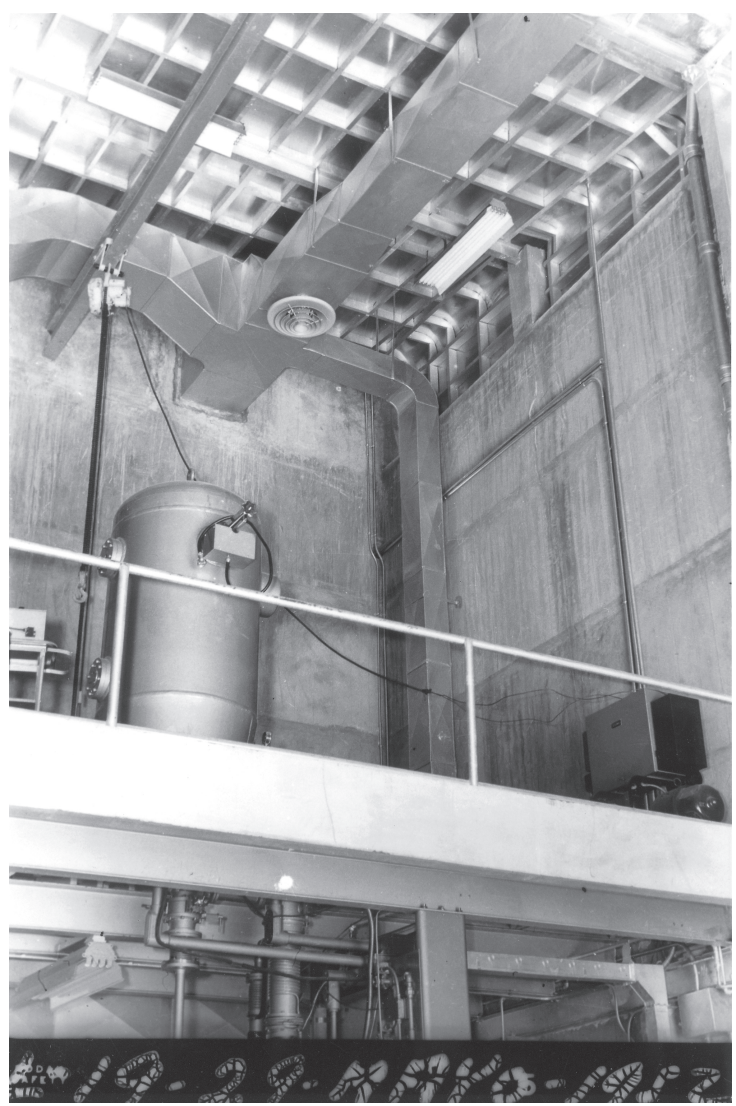

Figure 1. Van de Graaff accelerator, at Ciudad Universitaria, México (UNAM's campus). Source: Archivo Histórico de la Universidad Nacional Autónoma de México (AHUNAM).

The measures taken by the Mexican group showed the presence of radioactive material produced by the «recent atomic detonations in the Bikini Atoll and the Australian Sea». They also concluded that the distribution of atomic fallout dust was not uniform and that the methods of gummed paper and water surface were equivalent during the dry season. These results were published as a part of the UN Report on Atomic Fallout and in a Spanish version at the Revista Mexicana de Física ${ }^{41}$. From September 


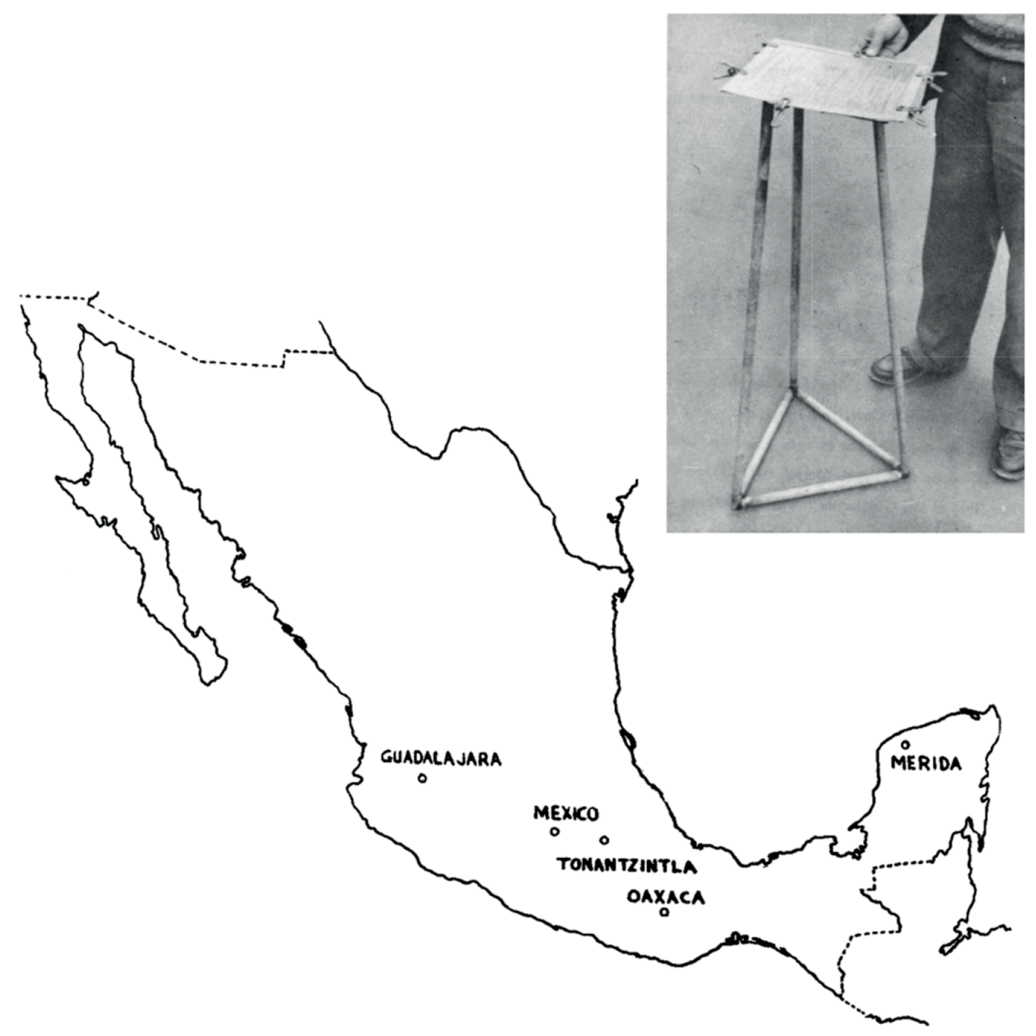

Figure 2. Experimental arrangement for atomic fallout measurement at different locations in Mexico. Source: Andrade, Fernando; Beltrán, Virgilio; Brody, Tomás A. et al. Primer informe sobre los estudios de lluvia radioactiva. Revista Mexicana de Física. 1956; 5 (4): 153-166.

1956 to February 1957 the number of stations taking fallout measurements was extended to Oaxaca, Mérida and Guadalajara ${ }^{42}$. The samples travelled by car or by plane to Mexico City, where they were analyzed by the atomic

42. Alba Andrade, Fernando; Brody, Tomás; Lezama, Héctor et al. Segundo informe sobre los estudios de lluvia radioactiva. Revista Mexicana de Física. 1957; 6 (2): 97-104; Brody, Tomás; Alba Andrade, Fernando; Cameras, Ricardo et al. Tercer informe sobre los estudios de la precipitación radioactiva. Revista Mexicana de Física. 1958; 7 (1): 1-26; Alba Andrade, Fernando; Brody, Tomás; Palacios, Adelaida, et al. Cuarto informe sobre los estudios de precipitación radioactiva. Revista Mexicana de Física. 1959; 8 (1): 61-84; Brody, Tomás; Bulbulian, Silvia; Calvillo, José et al. Quinto informe sobre los estudios de la precipitación radioactiva; Revista Mexicana de Física. 1962; 11 (1): 1-30. 
fallout group and afterwards collected at the US AEC. Before arriving at their final destination in the US, however, they had made use of local resources and infrastructures.

On the Mexican side the atomic fallout network opened the opportunity for the first generation of radio-chemists to be trained. Since 1954 Mexican scientists had participated in the first courses on radioisotopes offered at the ORNL. The physicist Fernando Alba Andrade was the first Mexican to assist to the radioisotope training course, and in 1955 the chemist Augusto Moreno Moreno and the physicist Ariel Tejera had joined the courses. Afterwards Moreno and Tejera elaborated the Spanish manual for the Mexican courses, which were offered starting in 1958 in Mexico City, by the joint participation of UNAM and the CNEN (figure 3).

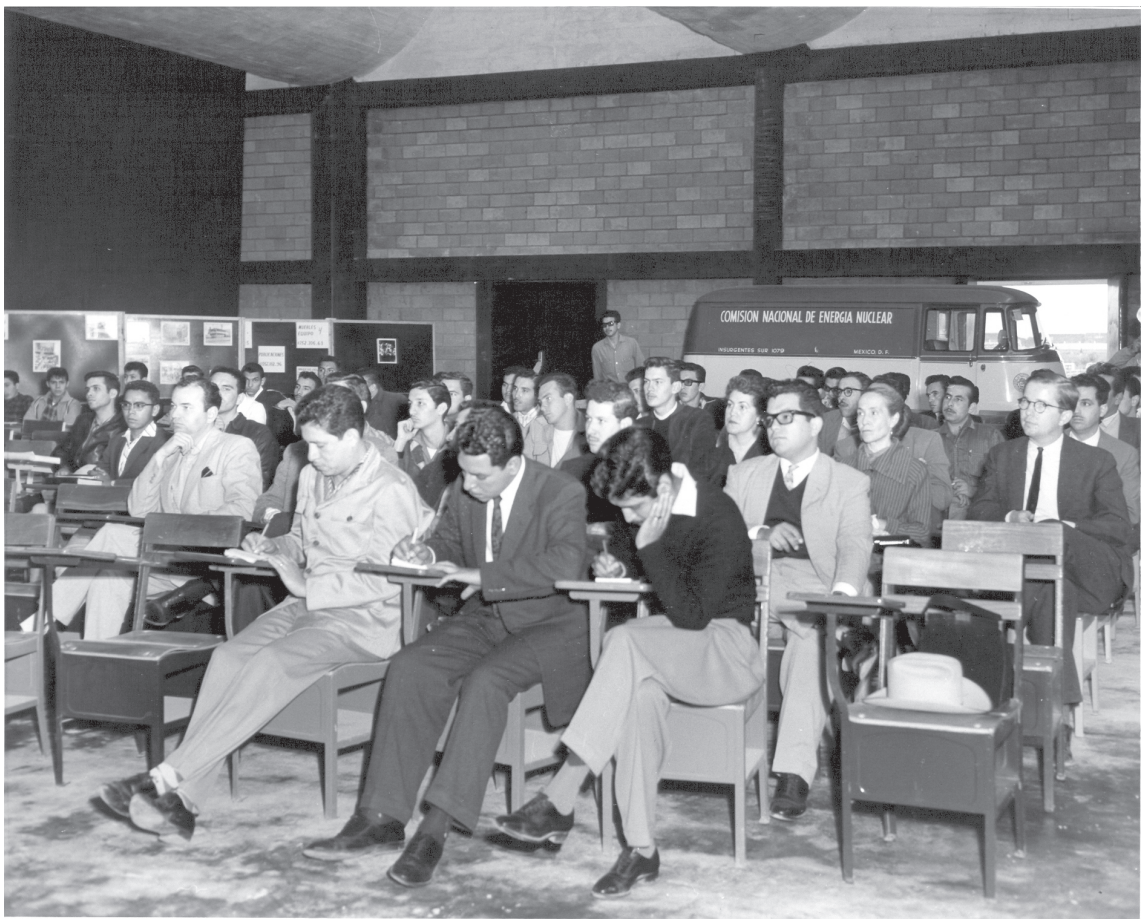

Figure 3. Radioisotope courses at the Comisión Nacional de Energía Nuclear, México. Source: Archivo del Instituto Nacional de Investigaciones Nucleares. 


\section{Producing, preparing and packing radioisotopes in Mexico}

With the creation of the IAEA in 1957 and the Inter-American Nuclear Energy Commission (IANEC), funding for training of Latin American specialists in nuclear issues increased, with an emphasis on the uses of radioisotopes in agriculture, medicine, and other peaceful applications which only indirectly required US technical assistance ${ }^{43}$.

During the late 1950s chemical engineer Tomas Brody and Alba Andrade were in charge of radiochemistry research in Mexico; but soon a group of women took the lead. In September 1957 chemical engineer Adelaida Palacios was invited by Brody to do research on the presence of 90Strontium in milk and biological materials. Palacios published the first Mexican paper on radiochemistry in $1959^{44}$. One year later, chemist Ana María Martínez became part of the group. Sadly, Adelaida Palacios died in 1959, although women continued to dominate the field.

In 1961 the Radioisotope Dilution and Radioactive Patterns Laboratory was created at the CNEN, under the supervision of Ariel Tejera, who had taken the ORNL radioisotope courses in $1955^{45}$. As mentioned, the team included many women: chemical engineer Ninfa Guerrero, MSc Ana María Martínez-Leal, and the chemist and physicist Silvia BulbuliánGarabedian ${ }^{46}$. Later on, María Eugenia Ramírez de Arellano became the head of the laboratory, followed up by Bulbulián and, at the beginning of the 1970s the group was in charge of another woman, Guerrero. Later on, a group was created which specialized on nuclear chemistry, and again

43. For other parts of the world see Hamblin, Jacob. Let there be light... and bread: the United Nations; the developing world; and atomic energy's Green Revolution. History and Technology. 2009; 25 (1): 25-48; Zachmann, Karin. Atoms for peace and radiation for safety - how to build trust in irradiated foods in Cold War Europe and beyond. History and Technology. 2011; 27 (1): 65-90; Zachmann, Karin. Risk rays for an improved food supply? National and transnational food irradiation research as a Cold War recipe. Deutches Museum. Preprint 7; 2013.

44. Bulbulian, Silvia; Rivero Espejel, Ignacio A. Historia de la investigación de la radioactividad en el Instituto Nacional de Investigaciones Nucleares. Boletín de la Sociedad Química de México. 2012; 6 (1): 15-26. Palacios, Adelaida; Brody, Tomás; Martínez-Leal Ana María. Métodos de determinación del estroncio 90. Revista Mexicana de Física. 1959; 8 (1): 27-41.

45. The history and impact of the radioisotope courses at Oak Ridge is still to be written. Angela Creager has called attention to it, but much remains to be done. For the British courses see Herran, Néstor. Spreading nucleonics: The Isotope School at the Atomic Energy Research Establishment, 1951-67. British Journal for the History of Science. 2006; 39: 569-586.

46. Bulbulián; Rivero Espejel, n. 44. 
Ramírez de Arellano was in charge. Henry Maddock, a radio-chemist from the Department of Chemistry at Cambridge University, often traveled to Mexico City to assist the Radiochemistry Group, always with support from IAEA technical assistance funds. More women were incorporated in the following decades, including Nuria Segovia, Dolores Tenorio, Suilma Marisela Fernández Valverde, and Melania Jiménez Reyes. Both groups became the central locus where radioisotopes were produced, prepared and distributed in Mexico between the mid-1960s and the 1970s (up to now there is a strong presence of women).

A favorable institutional and political context, and a historically long presence of women in Mexican chemistry, seem to account for the conspicuously dominance of women in radiochemistry ${ }^{47}$. The National School of Chemical Sciences had opened in 1919 (with antecedents in the previous century) as part of the National University of Mexico, and starting in 1925 the first woman graduated on chemical engineering. By the 1950s almost two hundred women had graduated in chemical pharmaceutics, and almost one hundred in chemical engineering. Moreover, as mentioned before, the 1950s were a time for modernization in Mexico, and chemists, chemical engineers and chemical pharmaceuticals were required in the growing metallurgic, oil, textile and other manufacturing activities. The academic setting, however, was not open for women, who were confronted with several obstacles in their pursuing of graduate studies in the established fields. Nevertheless, radiochemistry was a new area of research, less prestigious than physics and requiring skilled hands and a willingness to participate in a nouvelle setting; thus, the entrance of women into the field was a highly contingent matter ${ }^{48}$.

47. From the early decades of the 20th century chemistry seemed a friendly field for educated women: the catholic women's-only Motolinia University (opened in 1918) offered a degree in pharmaco-chemistry. See: González Vargas, Elena. Mujeres universitarias profesionales de la química mexicana del siglo XX. México: Universidad Autónoma del Estado de México; 2013; y Duran-Domínguez de Bazúa, María del Carmen. La mujer en la Ingeniería Química de México. Segundo Foro Nacional «La mujer en la Ingeniería Química de México», marzo de 2013.

48. The dominant presence of women in Mexican radiochemistry resonates with the highly contextual explanation of women in radioactivity research in Vienna. Rentetzi, Maria. Gender, Politics and radioactivity research in Interwar Vienna. Isis; 95 (3): 359-393. There is scarce historical research on Mexican women in science; most of it consists of narratives of women scientists' stereotypes and concentrate on personal dispositions and achievements, though the numbers and data provided might be useful for further analysis (see n. 47). During 
The first radioisotope (131I) purchased by the CNEN had been imported from Canada in 1962 for therapeutic uses at the Mexican Institute of Social Security (IMSS); the place of origin reveals Mexican efforts not to be completely dependent on the US. Nevertheless, the ORNL was still an important provider for the Mexican users well into the late 1960s, while the Dilution Laboratory was in charge of purchases, normalization, preparation, and distribution of radioisotopes within the country ${ }^{49}$. Mexico did not produce radioisotopes until the late 1960s, but in 1962 chemist Silvia Bulbulián produced 131I as part of her physics undergraduate thesis; for that, she used the experimental reactor from the Atoms in Action exhibition that took place in Mexico City between April 2nd and May 1st, $1962^{50}$. The exhibition was part of the US AEC's propaganda activities organized around the world by the US Information Agency (USIA) and according to local attendants it was a big success ${ }^{51}$. The situation changed after Mexico acquired its first research reactor, a Triga Mark III. The reactor was bought to the US with the mediation of the IAEA in 1966. This decision ran counter to the original plan of the Phoenix Project to build a Mexican research reactor in collaboration with the FDAP and Michigan University ${ }^{52}$.

The reactor was located at the newly built Nuclear Center located in Salazar, nearby Mexico City, where the Dilution Laboratory and the Reactor's team had been the first ones to move, in 1966. The reactor began to work in October of 1968 (figure 4), and from that moment radioisotope production took place in Mexico. Already in 1969 the radioisotopes produced reportedly included Sodium-24, Molibden-99, Tecnecium-99, Iodine-131, and Gold-198. Some of them had been produced for specific clients, and some for general uses in therapeutic, industrial, and research applications.

an interview with radiochemist Sofia Guillermina Burillo (27 Aug 2014); she recounts the obstacles she confronted when trying to do graduate studies in chemical engineering and biochemistry. The master's degree on radiochemistry opened in 1967 at UNAM, and she was part of the first generation.

49. Anónimo. Memoria de Labores de la CNEN 1968-1969. p. 38. México: CNEN; 1969.

50. Bulbulian, Silvia. Producción de Yodo 131. México: Universidad Nacional Autónoma de México; 1963.

51. Bulbulián; Rivero, n. 44.

52. For a personal account on the decisión making process, see Vélez Ocón, n. 6. 


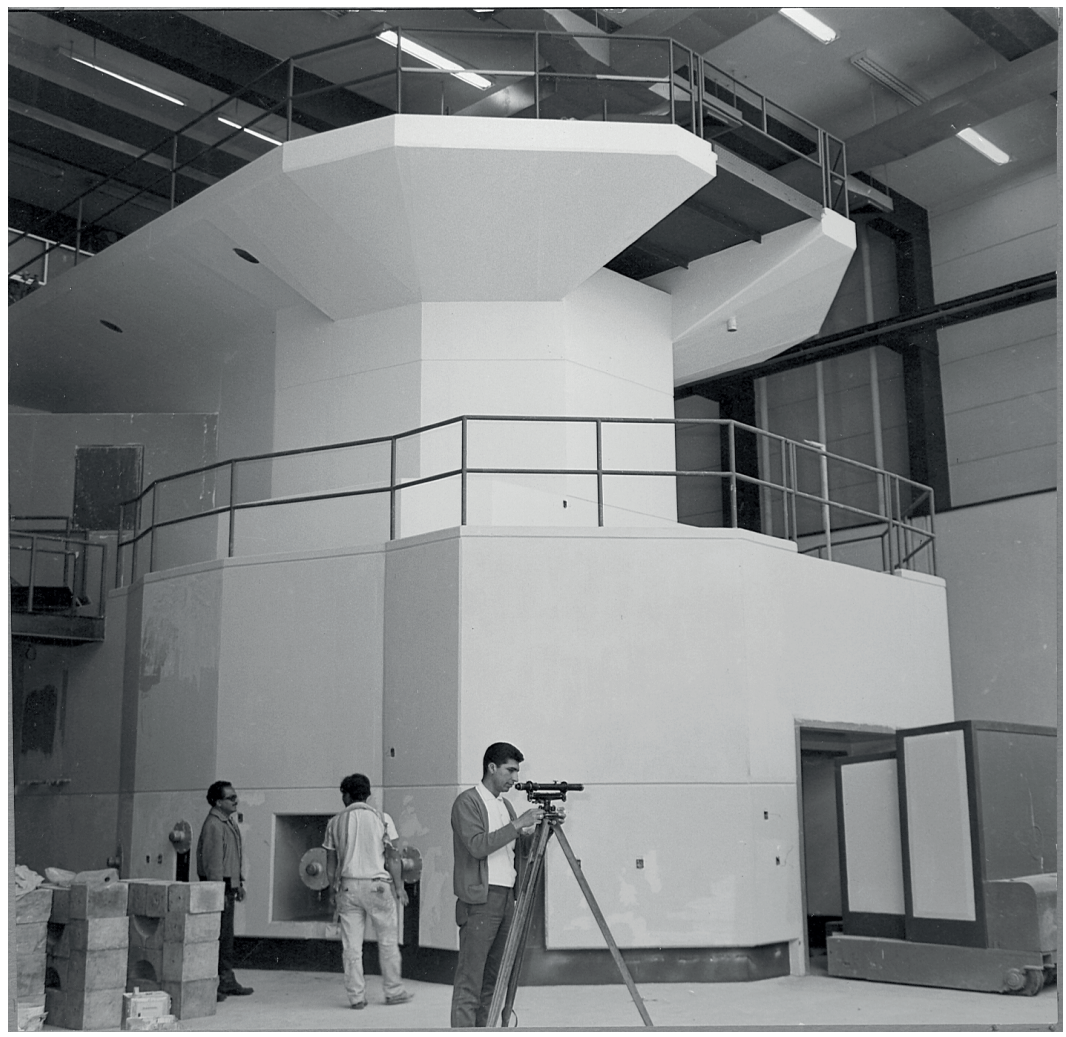

Figure 4. TrigaMark III reactor at Salazar Center in Mexico, circa 1968. Source: IAEA Archive.

They were produced, diluted, packed and distributed in the Mexican territory, with a stronger presence in the central and northern regions of the country. National distribution of diluted radioisotopes from the CNEN reached 3,360 shipments to 67 users in different parts of the country by 1968, mostly in the central part of Mexico as well as the major cities of Puebla, Guanajuato and Monterrey. Importation of radioisotopes gradually became less important; however, in the period 1968-1969, 28 different radioisotopes were still imported in more than 1,000 shipments ${ }^{53}$.

53. Reporte de actividades CNEN 1968-1969. Archivo General de la Nación (AGN), Mexico City. Acervo de la CNEN; Boxes 10-14. 
Very soon the CNEN began to produce a new type of material: marked biological molecules for research and medical diagnostic purposes. With technical assistance from the IAEA, methods to produce these molecules were implemented and new compounds produced. The CNEN was also producing, for the first time, short-lived radioisotopes which could not be imported, including Fluorine-18 and Strontium-87. The yearly report emphasized the importance of the new materials for scientific research, and indeed, the Mexican markers were being distributed to several research institutes and faculties at UNAM and other laboratories ${ }^{54}$. Although the main consumer was the medical sector, between 1970 and 1974 the demand for research radioisotopes augmented, as government agencies and universities increased their use. These places included not only the UNAM, but the IPN, the Mexican Oil Institute (IMP), the CINVESTAV (Centro de Investigaciones y Estudios Avanzados of the IPN), as well as hospitals and private laboratories and clinics. The dimensions of the distribution network required the establishment of a large and busy administrative apparatus at the CNEN, where a file exists for each client ${ }^{55}$.

Despite the overwhelming mass of archival material on accounts, checks, and bank transactions, it is not easy to calculate the price of radioisotopes in the period or the specific radioisotopes being sold to each client. However, there is an exceptional document of the Hospital Infantil de México (Children's Hospital) account which points out that on March 1971 the price of $.01 \mathrm{mCi}$ of $131 \mathrm{I}$ was $\$ 110$ Mexican pesos, the equivalent to $\$ 9.00$ USD of the time; in comparison an analytical balance cost was $\$ 1,484.00$ $\mathrm{USD}^{56}$. What the Mexican National Archive (AGN) allows us to infer is the relevance, translated into bureaucratic complexity and paper technologies, of the radioisotope distribution program in Mexico during those years. Following the new safeguards and international regulations established by the IAEA and later by the Latin American Non-proliferation Atomic Weapons Treaty, the CNEN concentrated and controlled the distribution of radioactive materials within Mexican territory thus becoming the main agent of Mexico's nuclearization.

\footnotetext{
54. Reporte de actividades CNEN 1968-1969, n. 53, p. 36

55. AGN Acervo CNEN, Boxes 10-14, Files 386-593. Unfortunately no detailed information is available at the CNEN files concerning overall consumption by the medical and research sectors.

56. AGN, Acervo CNEN, Requisiciones del Programa de Tecnología, 1972. Box 20, File 841.
} 


\section{Concluding remarks}

In contrast to other Latin American countries, Mexican nuclearization was and still is defined by its fierce commitment to the peaceful applications of atomic energy. One of the few Nobel Prizes awarded to Mexico was given in 1982 to Alfonso García Robles, for the promotion of the first non-proliferation of atomic weapons treaty, the so called Tlatelolco Treaty (signed in Mexico City in 1967), which made Latin America the world's first atomic weapons free-zone. As a national project, denuclearization was a mode of nuclearity ${ }^{57}$. It meant a geopolitical pacifist position and a research program restricted to the peaceful uses of atomic energy. In this context, radioisotopes had a privileged role to play: they were imported, produced, distributed, and used for medicine, agriculture, biomedical, and geological research, archaeology, and industry. Moreover, we have come to see Mexican science during the Cold War as deeply shaped by what we call the effects of denuclearization: popular distaste towards atomic weapons, different resentments towards US' foreign policies - shaped by an everpresent post-revolutionary nationalism-, pacifist high-level diplomacy and, ultimately, the promotion of the Tlatelolco Treaty ${ }^{58}$.

The nuclearization program was under the complete control of the nationalist and modernist executive branch of the Mexican state, which in that period meant that techno-political decisions were taken only by a few actors. Mexican citizenship did not play an active role in atomic issues in that period $^{59}$. But scientific experts, even if allied with the government, did not always speak in a unanimous voice. For instance, debates during the 1960's

57. Here we use Gabrielle Hecht's definition of nuclearity: «the degree to which a nation, a program, a policy, a technology, or even a material counted as "nuclear" — [it]was a spectrum, not an on-off condition. Both nuclearity and its implications emerged in substantive ways from the dynamics between Cold War and postcolonial visions of the world». Hecht, Gabrielle. Negotiating global nuclearities: Apartheid, Decolonization, and the Cold War in the making of the IAEA. Osiris. 2006; 21: 25-48 (26-27). Nuclearity makes reference to a socio-technical classification of Mexico within the nuclear spectrum; in contrast to our use of nuclearization, as a historical category.

58. Gisela, Mateos; Suárez-Díaz, Edna. Tensions between becoming nuclear and promoting denuclearization: Mexican Nuclear Politics, 1950-1970. Conference Dark Matters: Contents and Discontents in Science during the Cold War, 2013 [unpublished paper].

59. On the scarce involvement of Latin American societies in the fallout debates of the 1950s, and the anti-nuke movement, Wittner, Lawrence. Resisting the bomb. A history of the world nuclear disarmament movement, 1954-1970. California: Stanford University Press; 1997. 
about which reactor technologies to acquire - uranium or heavy waterwere translated into debates on dependency from the US for fuel supply versus national sovereignty and technological development ${ }^{60}$. Eventually, for reasons of national security and a more-than-a-century-long-distrust towards their US neighbors, the Mexicans decided to acquire a nuclear (US) research reactor, but through the mediation of the IAEA (a history that we will pursue in another paper).

As a transnational model, the discourse of development not only dominated the North-South relations during the period, but created the very dichotomy of a developed and an underdeveloped world. The «imagined geographies» - representing the First World and the Third World-, cut the world along a line that implied the transfer of science and technologies in one direction, but the obligation to give and accept (different things and symbols) in two directions. Development projects ignored the local context and were defined as exogenous programs to be applied without further consultation with local communities ${ }^{61}$. However, as we have seen, the Mexican scientists and promoters of nuclear energy were highly active and had their own perspective and priorities on the matter. Nevertheless, it is clear that their relation to their American counterparts was of a nonreciprocal character, and situated in an asymmetrical field of power ${ }^{62}$. In this context, the uses of nuclear technologies were understood as one of the high points of development policies during these decades; this fact was recognized by all parts involved. Nevertheless, tensions and synergies between modernity and nationalism took place, eventually restricting the

60. Vélez Ocón, n. 6.

61. There is a growing amount of literature on development and the Cold War, and the Cold War in Latin America. For instance, Escobar, Arturo. Encountering development. The making and unmaking of the third world. Princeton: Princeton University Press; 1994; Moon, Suzanne. Takeoff or self-sufficiency ideologies of development in Indonesia, 1957-1961. Technology and Culture. 1998; 39 (2): 187-212; Nick Cullather. The hungry world. America's Cold War battle against poverty in Asia. Cambridge: Harvard University Press; 2010. Cullather's first chapter deals with the Mexican Green Revolution. On Latin America's Cold War, Gilbert, Joseph; Spenser, Daniela. In from the Cold: Latin America's new encounter with the Cold War. Durham: Duke University Press; 2008; Brand, Hal. Latin America's Cold War. Cambridge: Harvard University Press; 2012.

62. For a characterization of reciprocal relations in an asymmetrical field of power (USA-UK relations), Krige, John. Hybrid knowledge. The transnational coproduction of the gas centrifuge for uranium enrichment in the 1960s. British Journal for the History of Science. 2012; 45(3): 337-357. 
uses of nuclear technologies in Mexico in order to keep the nationalistic and non-aligned (for internal consumption) foreign affairs policy ${ }^{63}$.

Finally, radioisotopes do not travel by themselves, as Santesmases has argued ${ }^{64}$. As we followed them, we have brought to light a broad diversity of actors, in different countries and with different roles in our history. Radioisotopes also travelled with meanings and implicit or explicit commitments that remind us of Marcel Mauss' concept of gift exchange where «to refuse to give $[. .$.$] is-like refusing to accept [...] a refusal of friendship» { }^{65}$. For the Mexican scientists radioisotopes implied resources, international presence, prestige among their national peers, growth and consolidation of the scientific community, access to Mexican policy-making decisions, but also obligations to comply with US constraints. Such constraints, however, changed and adopted more flexible ways as international organisms and national production took over importation from the US. At the national level, the radioisotope exchange implied a political alliance between two countries, which was portrayed as friendship and «cooperation». But it also implied supervision, distrust, and control of the knowledge and materials produced inside but also outside the US frontiers: Mexico did not produce enriched uranium or plutonium despite its mineral reserves (which later on proved to be of low quality materials), and this fact only deepened with the promotion of the Tlatelolco Treaty. Claims of cooperation and collaboration, thus, must be analyzed in their nuanced multi-valent meanings, and with their created obligations attached. They do not imply a symmetrical exchange or a reciprocal relation, in particular when we deal with NorthSouth transactions; but it would be misleading to locate all sources of power on just one side of the long US-Mexico border. Mexico, as we have seen, developed a national path towards nuclearization between the 1950s and 1960s, which aimed to preserve its autonomy and sovereignty, while at the same time exerting a visible international presence.

\footnotetext{
63. Keller, n. 34.

64. Santesmases, n. 5.

65. Mauss, Marcel. The gift. Forms and functions of exchange in archaic societies. London: Cohen \& West Ltd; 1966, p. 11.
} 


\section{Acknowledgments}

Our views on Mexican nuclearization owe a lot to the generous exchanges and previous research carried out by many colleagues: Angela Creager, María Jesús Santesmases, John Krige, Soraya de Chadarevian, Jahnavi Phalkey, Jessica Wang, Karin Zachmann, and Jacob Darwin Hamblin, and two anonymous referees. We also thank the generous collaboration of Silvia Bulbulián, Guillermina Burillo, Eugenio Ley Koo, Saúl Romero and Guillermo Espinoza, who shared their remembrances with us. 